\title{
Earnings management: the effects of national audit environment, audit quality and international capital markets
}

\author{
Citation for published version (APA):
}

Maijoor, S. J., \& Vanstraelen, A. (2002). Earnings management: the effects of national audit environment, audit quality and international capital markets. METEOR, Maastricht University School of Business and Economics. METEOR Research Memorandum No. 070 https://doi.org/10.26481/umamet.2002070

Document status and date:

Published: 01/01/2002

DOI:

10.26481/umamet.2002070

Document Version:

Publisher's PDF, also known as Version of record

\section{Please check the document version of this publication:}

- A submitted manuscript is the version of the article upon submission and before peer-review. There can be important differences between the submitted version and the official published version of record. People interested in the research are advised to contact the author for the final version of the publication, or visit the DOI to the publisher's website.

- The final author version and the galley proof are versions of the publication after peer review.

- The final published version features the final layout of the paper including the volume, issue and page numbers.

Link to publication

\footnotetext{
General rights rights.

- You may freely distribute the URL identifying the publication in the public portal. please follow below link for the End User Agreement:

www.umlib.nl/taverne-license

Take down policy

If you believe that this document breaches copyright please contact us at:

repository@maastrichtuniversity.nl

providing details and we will investigate your claim.
}

Copyright and moral rights for the publications made accessible in the public portal are retained by the authors and/or other copyright owners and it is a condition of accessing publications that users recognise and abide by the legal requirements associated with these

- Users may download and print one copy of any publication from the public portal for the purpose of private study or research.

- You may not further distribute the material or use it for any profit-making activity or commercial gain

If the publication is distributed under the terms of Article $25 \mathrm{fa}$ of the Dutch Copyright Act, indicated by the "Taverne" license above, 


\title{
Earnings Management:
}

\section{The Effects of National Audit Environment, Audit Quality and International Capital Markets}

\author{
by \\ Steven J. Maijoor \\ Universiteit Maastricht \\ Maastricht, The Netherlands \\ and \\ Ann Vanstraelen \\ Universiteit Maastricht \\ Maastricht, The Netherlands
}

January 2002

Please Do Not Quote Without Permission 


\title{
Earnings Management:
}

\section{The Effects of National Audit Environment, Audit Quality and International Capital Markets}

\begin{abstract}
This paper studies earnings management in an international context. More specifically, the effects of three factors on earnings management are studied: national audit environment, audit firm quality and reliance on international capital markets. National audit environments vary strongly in terms of independence rules, auditor education and auditor liability. Hence, it can be expected that the restrictions imposed by national audit environments on earnings management vary. However, there are two factors that can mitigate the national audit environment effect. First, there is strong evidence that audit firm quality, as indicated by the Big 5 and non-Big 5 dichotomy, affects earnings management opportunities for clients. In the context of this study an important issue is to what extent this quality effect overrides national differences. In other words, to what extent do the international audit firms provide a standardized high quality audit across different jurisdictions? Second, the reliance on international capital markets might reduce companies' earnings management, irrespective of the opportunities provided by the national environment.

The study uses data for the period 1991 - 1999 from listed firms in four jurisdictions: France, UK, the Netherlands and Germany. The total number of firm year observations is 17,838. The results of the study suggest that national differences in audit environments are strongly affecting earnings management. While earnings management is also affected by the audit quality of the audit firm and the reliance on international capital markets, the effect is rather small.

The evidence provided in this study is relevant for the current worldwide integration of capital markets and the acceptance of international accounting standards. For the international comparability of earnings, not only the standardization of financial reporting is important but also the standardization of enforcement across jurisdictions. The results of this study suggest that the enforcement of financial reporting still varies strongly across countries.
\end{abstract}




\section{Introduction}

This study examines the effects of differences in audit firm quality and national audit environment on earnings management. Our paper contributes to the literature in three ways. First, Gore et al. (2001) pointed out that there is an "increasing interest in the impact of different economic environments and GAAP regimes on the attributes of accounting earnings (Pope and Walker, 1999; Ali and Hwang, 2000; Ball et al., 2000) and on the incidence of earnings and forecast management (Brown and Higgins, 1999; Leuz et al., 2000)". Our paper contributes to this increasing interest by analysing the incidence of earnings management in four European countries: France, Germany, the Netherlands and the United Kingdom. These four countries vary in terms of their audit environment (independence rules, auditor education and auditor liability). We do not only provide descriptive rankings of these countries in terms of earnings management (see Leuz et al, 2000), but also perform univariate and multivariate statistical analyses to identify both the audit firm quality effects and the national audit environment effects.

Secondly, we consider whether Big 5 auditors constitute a constraint on earnings management in the four European countries under study and if so, whether this constraint is uniform across countries.

Finally, we consider whether a foreign exchange listing or a New York Stock Exchange (NYSE) listing influences the incidence of earnings management. It could be argued that companies relying on international capital markets, compared to companies relying on national capital markets, have different incentives and constraints with respect to earnings management.

The results of this study are relevant for the current discussion on the international comparability of financial statements, and specifically the comparability of earnings. It is assumed that the acceptance of an international set of accounting standards, like the 
International Accounting Standards (IASs), will be an important step in the international comparability of financial statements. However, the international comparability of earnings reported not only depends on the set of accepted accounting standards, but also on the national quality of audits and the constraints imposed on earnings management by the national audit environment.

Related to this issue is whether the Big Five provide the same audit quality across countries. While the minimum levels of national audit quality might vary from country to country, it could be argued that the Big Five audit firms have a strong incentive to provide the same high audit quality level in different countries. The reason is that their clients attract capital from international markets.

The evidence in the paper clearly indicates that companies in the European countries included in the study, France, Germany, the Netherlands and the UK, engage in earnings management. Companies tend to avoid small losses and prefer to report small profits instead. However, the magnitude of earnings management is not uniform across the four countries. In particular, the results suggest that companies in countries with a strict audit quality regime engage less in earnings management compared to companies in countries with a more flexible audit regime. The presence of a Big 5 audit firm is not capable of eliminating all of these significant country differences. Finally, it is shown that a listing on a foreign stock exchange for companies audited by a Big 5 audit firm constitutes a constraint on the incidence of earnings management. 


\section{Previous Literature}

International differences in earnings management

Ball et al. (2000) suggest that the demand for accounting earnings is systematically different in code-law countries versus common-law countries. Common-law countries are characterized by: transactions at "arms-length"; a diverse base of investors; and a relatively high risk of litigation. In code-law countries, capital markets are less active. Companies are more financed by banks, other financial institutions and the government, which results in less need for public disclosure. Moreover, litigation rates are relatively low.

Leuz et al. (2000) provide evidence that earnings management and loss avoidance practices are more prevalent in companies from code-law countries compared to common-law countries. It is argued that the costs (e.g. litigation) and benefits (e.g. enhanced liquidity) for engaging in earnings management differ for managers and auditors in code-law countries versus common-law countries. The expected benefits of earnings management appear to outweigh the expected costs for a firm in a code-law country.

\section{Audit constraint on earnings management}

Evidence has been provided that Big $5^{1}$ audit firms constitute a constraint on earnings management. DeFond and Jiambalvo (1991) show that non-fraudulent clients of Big 5 auditors are less likely to have errors or irregularities, which were considered to be a proxy for earnings management. In a subsequent study, DeFond and Jiambalvo (1993) provided evidence that auditor-client disagreements, resulting from incentives to manage earnings, are more likely to occur in case of a Big 5 auditor.

Becker et al. (1998) provide evidence that clients of non-Big 5 auditors report discretionary accruals that increase income relatively more than the discretionary accruals

\footnotetext{
${ }^{1}$ For convenience, this paper uses the term 'Big 5 auditor' to identify the large international audit firm networks. Some of the studies referred to were conducted before the mergers resulted in the reduction to 5 international audit networks.
} 
reported by clients of Big 5 auditors. Moreover, it was found that the mean and median of the absolute value of discretionary accruals are greater for firms with non-Big 5 auditors.

Francis et al. (1999) report for a sample of NASDAQ firms that, even though Big 5 auditors have higher levels of total accruals, they also have lower amounts of estimated discretionary accruals.

For UK firms, Gore et al. (2001) show that Big 5 auditors are more able to constrain earnings management than non-Big 5 auditors in the case that a high level of non-audit services is provided, measured by the ratio of non-audit fees to total fees.

\section{Measures of earnings management}

Different models have been suggested in the literature to measure earnings management. Healy and Whalen (1999) and Young (1999) provide a good overview of the earnings management literature and the different models used to measure earnings management. We examine both earnings distributions (see Hayn, 1995; Burgstahler and Dichev, 1997; Degeorge et al., 1999; Gore et al., 2001) and working capital accruals (see Dechow et al.1995; DeFond and Park, 1999; Peasnell et al., 2000) to detect earnings management.

\section{Development of Hypotheses}

The main argument in this paper concerns the effects of national laws and regulations regarding auditing on earnings management by companies.

Hypothesis 1: Ceteris paribus, firms in countries with strict audit quality regimes report relatively lower absolute values of discretionary accruals compared to firms in countries with flexible audit quality regimes. 
It can be expected that the impact of the type of audit quality regime on earnings management is influenced by the type of audit firm. This expectation is based on the argument that Big 5 audit firms attempt to control the quality of their audits across jurisdictions. As the production of their audits is based on internationally recognized brand names, they have an incentive to provide a uniform level of audit quality in different countries. Consequently, it is hypothesised that:

Hypothesis 2: Ceteris paribus, the magnitude of the absolute value of discretionary accruals is less affected by the type of audit quality regime, in case of a Big 5 audit firm compared to a non-Big 5 audit firm.

While the national laws and regulations might set a minimum level of audit quality, companies and their auditors might voluntarily opt for a higher audit quality level for capital market reasons. Companies relying on international capital markets do not only take the restrictions imposed by their national market into account, but also restrictions from other countries. For example, a Dutch company listed on the NYSE, is also affected by the restrictions imposed by the SEC. It can be expected that this will affect the level of earnings management by the Dutch company.

Hypothesis 3: Ceteris paribus, companies with international sources of capital will report relatively lower absolute values of discretionary accruals compared to firms with national sources of capital.

Buijink et al. (1996) provides a detailed description of the auditing laws and regulations in the Member States of the European Union. On the basis of that description, the regulatory 
systems in the countries included in this study are ranked as follows from a relatively strict audit quality regime to a more flexible audit quality regime: France; UK; the Netherlands; and Germany. This classification is motivated by the presence or absence of laws and regulations, which aim to promote audit quality in these countries. Table 1 provides an overview of these laws and regulations.

- INSERT TABLE 1-

France is the country that has the highest number of laws and regulations that intend to improve audit quality. In particular, France imposes restrictions on the minimal length of the audit mandate. Moreover, management advisory services and advertising are not allowed. Statutory auditors are subject to reviews by peers and regulators. Listed firms are required to have a joint audit and the appointment of the statutory auditor has to be approved. The UK is classified as the country with the second highest strict audit quality regime due to the high risk of litigation. The Netherlands and Germany have more or less the same limited number of laws and regulations to safeguard audit quality. However, since the risk of litigation is considered to be higher in the Netherlands than in Germany (see Blij et al., 1998), the Netherlands is ranked in the third position in terms of strictness of audit quality regime.

\section{Sample Selection}

To collect data for this study, we used the June 2000 version of the Worldscope database. Data are collected for France, Germany, the Netherlands and the United Kingdom. All four countries have currently sizable and well-developed capital markets, but vary significantly in their regulatory regimes regarding auditing (Buijink et al. 1996). Data were collected for the period 1991-1999, resulting in a total of 29,628 firm year observations (France: 6822; 
Germany: 7083; the Netherlands: 1809; UK: 13,914). Consistent with previous research (e.g. Becker et al. 1998), financial institutions (SIC 6000-6999) and utility companies (SIC 40004999) were excluded. Due to data limitations, the number of usable observations is reduced to 17,838 (France: 3904; Germany: 3992; the Netherlands: 1244; UK: 8698). In most cases, for the companies that needed to be removed from the database, information was missing on their net income, especially in the early years of the period under study. All companies in our sample are listed firms.

\section{Research Design}

Our paper builds on the research method applied by Gore et al. (2001). They showed that earnings in the UK are distributed discontinuously around zero (small loss avoidance and achieve small profits), which is consistent with the results found in the US (Hayn, 1995; Burgstahler and Dichev, 1997; Degeorge et al., 1999). However, Gore et al. (2001) show that the exclusion of discretionary accruals from current earnings causes the discontinuity to disappear. In other words, their results suggest an explicit link between working capital accruals earnings management and a discontinuity in the distribution of earnings around zero. This finding motivates our choice to examine both earnings distributions and working capital accruals to detect earnings management.

Consistent with Burgstahler and Dichev (1997), the statistical significance of small loss avoidance is tested by examining whether the cross-sectional distributions of earnings levels are relatively smooth. Smoothness is defined as follows: "the expected number of observations in any given interval is the average of the number of observations in the two immediately adjacent intervals (Burgstahler and Dichev, 1997)”. Operationally, the statistical test used to test smoothness is defined as follows (Burgstahler and Dichev, 1997): 
Standardized difference $=($ Observed number of observations in an interval - Expected number of observations in the interval) / Estimated standard deviation of difference

The estimated standard deviation of difference equals the square root of the following expression (Burgstahler and Dichev, 1997):

$(\text { Estimated standard deviation of difference })^{2}=N \cdot p_{i}\left(1-p_{i}\right)+1 / 4 \cdot N \cdot\left(p_{i-1}+p_{i+1}\right) \cdot\left(1-p_{i-1}-p_{i+1}\right)$ where:

$\mathrm{N}=$ Number of observations;

$\mathrm{p}_{\mathrm{i}}=$ Probability that an observation will fall into interval $\mathrm{i}$;

$\mathrm{p}_{\mathrm{i}-1}=$ Probability that an observation will fall into interval $\mathrm{i}-1$;

$\mathrm{p}_{\mathrm{i}+1}=$ Probability that an observation will fall into interval $\mathrm{i}+1$.

Under the null hypothesis, the standardized difference follows a standard normal distribution with mean equal to zero and standard deviation equal to one (Burgstahler and Dichev, 1997). In the description of the results, the standardized differences both left and right of zero are reported.

Next to earnings distributions, we also examine working capital accruals. Similar with DeFond and Park (1999), we define working capital accruals as the change in non-cash working capital (WC). Abnormal working capital accruals (AWCA) are defined as realized working capital accruals minus normal working capital accruals. Normal working capital is assumed to be a fixed proportion of sales (Dechow and Kothari, 1998; DeFond and Park, 1999). We approximate the expected working capital in the current year by the average working capital and sales of the three previous years. This gives the following expression:

$$
A W C A_{t}=W C_{t}-\left[\left(W C_{((t-1)+(t-2)+(t-3)) / 3)} / \operatorname{Sales}_{((t-1)+(t-2)+(t-3)) / 3)}\right) * S_{t}\right]
$$

where :

$\mathrm{AWCA}_{\mathrm{t}}=$ Abnormal working capital accruals in year t;

$\mathrm{WC}_{\mathrm{t}}=$ Working capital in year $\mathrm{t}$;

$\mathrm{WC}_{((t-1)+(t-2)+(t-3)) / 3)}=$ Average working capital in the three years preceding year $\mathrm{t}$; 
$\mathrm{S}_{\mathrm{t}}=$ Sales in year $\mathrm{t}$;

Sales $_{((t-1)+(t-2)+(t-3)) / 3)}=$ Average sales in the three years preceding year $\mathrm{t}$.

Subsequently, the abnormal working capital accruals of the year are scaled by the sales of that year.

Our empirical analysis will focus on the absolute total value of discretionary accruals. Previous studies in this area tend to focus on positive discretionary accruals. The reason being that auditors have a higher risk of reputation loss in the case of upward managed earnings compared to downward managed earnings. Hence, audit quality differences would especially be revealed in case of upward managed earnings. However, in the countries under study, there might be variations in the direction of the incentives to manage earnings. For example, in more tax-oriented reporting systems (e.g. Germany), audit quality might be revealed by limiting the opportunities for negative discretionary accruals. Therefore we will focus on earnings management per se. In this respect, Warfield et al. (1995) also indicated that the absolute value of discretionary accruals is a good proxy for the combined effect of incomeincreasing and income-decreasing earnings management decisions.

The three main variables of interest in this study are: (1) in which national auditing system the company operates; (2) whether the company is audited by a Big 5 or a non-Big 5 auditor; and (3) whether the company relies on international capital markets. The effect of the national audit regime is measured with a dummy variable for each country under study. The effect of international capital markets is measured with a variable indicating whether the company has a foreign exchange listing and a variable indicating whether the company is listed on the NYSE.

Consistent with previous studies on earnings management, the following variables are included in the model to control for earnings management incentives. First, we control for the size of a company proxied by the natural logarithm of total assets. It is argued in the literature that larger firms prefer upward earnings management due to political costs (see Young, 1999; 
Gore et al., 2001). Second, a leverage or gearing variable is included in the model (see Young, 1999; Gore et al., 2001). Highly leveraged firms may have an incentive for incomeincreasing earnings management in view of debt covenant violations (DeFond and Jiambalvo, 1994). Alternatively, high leverage may induce income-decreasing earnings management in financially distressed firms in view of contractual renegotiations (Becker et al., 1998). Third, we include a performance measure as a control variable. Consistent with Dechow et al. (1995) and Young (1999), we include cash flow from operating activities to control for underlying performance which may induce income-increasing earnings management. Finally, we include industry dummies to control for industry effects on earnings management incentives. Formally, the model looks as follows:

$$
\begin{aligned}
A W C A_{t}= & \beta_{0}+\beta_{1} U K+\beta_{2} F R A+\beta_{3} N E T H+\beta_{4} \text { BSNB5 }_{t}+\beta_{5} \text { FORLIST }_{t}+\beta_{6} N Y S E_{t}+ \\
& \beta_{7} \text { LNASSET }_{t}+\beta_{8} \text { GEAR }_{t}+\beta_{9} \text { OPCF }_{t}+\beta_{10} I N D_{i t}+\varepsilon_{t}
\end{aligned}
$$

where:

$\mathrm{AWCA}_{\mathrm{t}}=$ Abnormal working capital accruals in year $\mathrm{t}$;

$\mathrm{UK}=$ Dummy variable $(\mathrm{UK}$ company $=1$, else 0$)$;

$\mathrm{FRA}=$ Dummy variable $($ French company $=1$, else 0$) ;$

$\mathrm{NETH}=$ Dummy variable $($ Dutch company $=1$, else 0$)$;

$\mathrm{B}_{\mathrm{NB}} 5_{\mathrm{t}}=$ Dummy variable $($ Company has Big 5 auditor $=1$, else 0$)$;

FORLIST $_{\mathrm{t}}=$ Dummy variable (Company has a foreign listing $=1$, else 0$)$;

$\mathrm{NYSE}_{\mathrm{t}}=$ Dummy variable (Company is listed on the NYSE $=1$, else 0 );

LNASSET $_{t}=$ Natural logarithm of total assets in year t;

$\mathrm{GEAR}_{\mathrm{t}}=$ Ratio of long term debt over common equity in year $\mathrm{t}$;

$\mathrm{OPCF}_{\mathrm{t}}=$ Cash flow from operating activities in year $\mathrm{t}$.

$\mathrm{IND}_{\mathrm{it}}=$ Industry dummies (SIC 10-17: Mining \& Construction; SIC 20-39: Manufacturing; SIC 50-59: Wholesale trade; SIC 70-89: Services)

It is noted that Germany (German company $=1$, else 0 ) is the country of reference and SIC 01-09 (agriculture, forestry and fishing) is the industry of reference. 


\section{Empirical Results}

\section{Earnings distributions}

Table 2 presents the descriptive statistics of earnings scaled by beginning of year total assets for the period 1991-1999 across the four countries included in the study.

- INSERT TABLE 2 -

The distribution of scaled earnings for the pooled sample is illustrated in figure 1 .

- INSERT FIGURE 1 -

Figure 1 clearly shows a discontinuity around zero suggesting that European companies engage in earnings management. They prefer to avoid small losses and report small profits instead. The significance of this discontinuity is confirmed by the statistical tests, presented in Table 3.

- INSERT TABLE 3 -

Table 3 also reports the results of the distribution of scaled near-zero earnings for the individual countries. The results indicate that the irregularity around zero is significant in the four countries under study. These results are consistent with the findings in the UK (Gore et al., 2001) and in the US (Hayn, 1995; Burgstahler and Dichev, 1997; Degeorge et al., 1999).

\section{Working capital accruals}

The working capital accruals results relate to the year 1998. As stated earlier, we define abnormal working capital accruals as realized working capital accruals minus expected 
normal working capital accruals, measured by the average working capital and sales of the three previous years. Figures 2-5 illustrate the magnitude of abnormal working capital accruals in respectively France, Germany, the Netherlands and the UK.

\section{- INSERT FIGURES 2-5 -}

The figures clearly suggest that the magnitude of earnings management is the highest in Germany, followed by the Netherlands, the UK and France. This is also confirmed by the descriptive statistics presented in Table 4. This ranking corresponds with our postulated ranking of countries in terms of strictness of audit quality regime. Moreover, the ranking is consistent with the results reported by Leuz et al. (2000) comparing the magnitude of the absolute value of working accruals to the magnitude of the absolute value of operating cash flow across countries.

- INSERT TABLE 4 -

Table 5 presents the univariate results for the pooled sample and the four countries separately. The results of the pooled sample show that the magnitude of income-increasing earnings management is significantly higher than the magnitude of income-decreasing earnings management. Big 5 auditors constitute a constraint on both income-increasing and incomedecreasing earnings management. This result is significant for the pooled sample and the UK sample. Companies listed on a foreign stock exchange or on the NYSE tend to engage less in earnings management compared to companies that are not foreign listed, yet not significantly.

-INSERT TABLE 5 - 
The results of the differences in earnings management practices across France, Germany, the Netherlands and the UK are presented in table 6 . The test of means provide evidence that there are significant differences between these countries.

\section{-INSERT TABLE 6 -}

For the pooled sample, the results in panel A of table 6 show that German companies engage significantly more in earnings management compared to companies in the UK, the Netherlands and France. In addition, in the Netherlands companies engage significantly more in earnings management compared to the UK and France. The only country difference that is not significant is between France and the UK. These findings are in line with hypothesis 1 stating that firms in countries with a flexible audit regime report relatively higher absolute values of discretionary accruals.

In order to test whether the potential constraint of Big 5 auditors on earnings management is uniform across countries, the test of means is performed on the sample of companies with a Big 5 auditor and the sample of companies with a non-Big 5 auditor separately. The results are presented in table 6, panel B and C. For the sample of companies with a Big 5 auditor, panel B provides evidence that the difference across countries remain significant. This would suggest that the audit quality of Big 5 audit firms is not uniform across countries. For the sample of non-Big 5 audit firms, the results in panel $\mathrm{C}$ show that in Germany companies engage significantly more in earnings management compared to France and the UK. Surprisingly, the other country differences are no longer significant. These findings do not support hypothesis 2 . In contrast, the results imply that the flexibility of nonBig 5 audit firms in accepting earnings management is relatively uniform across countries, 
while the conservatism of Big 5 auditors in restricting earnings management does not appear to be uniform across countries.

Table 7 presents the OLS regression results with Germany as the country of reference.

\section{-INSERT TABLE 7-}

The multivariate results confirm the significant differences in the magnitude of earnings management across countries. Companies in the UK, the Netherlands and France engage significantly less in earnings management compared to Germany. A listing on a foreign stock exchange is a significant constraint on earnings management. Big 5 audit firms and a listing on the NYSE constitute a constraint on earnings management though not significantly. The variable cash flow from operating activities controlling for underlying performance is significantly negative, as predicted. Companies in the service industry (SIC 70-80) tend to engage significantly more in earnings management compared to other industries.

Ball et al. (2000) state that "code-law accounting standards give greater discretion to managers in deciding when economic gains and losses are incorporated in accounting income". Similarly, Leuz et al. (2000) show that earnings management appears to be more prevalent in code-law countries compared to common-law countries. Guenther and Young (2000) argue that in countries where there is conformity between financial accounting and tax accounting rules, "financial accounting information may differ from underlying economic activities because firms attempt to minimize taxable income". In this respect, it is tested whether the differences in results between the countries in our sample are not merely driven by potential differences in earnings management incentives between common-law versus code-law countries or conformity between financial and tax accounting rules. Therefore, the OLS regression is performed on an alternative model including a dummy variable for 
common-law (UK) versus code-law countries (Germany, France and the Netherlands) and a dummy variable for financial and tax accounting conformity (tax conformity in France and Germany), instead of the country dummies. The results, presented in table 8 , show that both the common/code-law country dummy and the financial/tax accounting conformity dummy are significantly negative. In addition, a Big 5 audit firm and a listing on a foreign stock exchange are significant constraints on earnings management. However, a comparison of the adjusted R-Squares shows that the model including the country dummies (adjusted R-Square: $26.1 \%$ ) outperforms the model including the common/code-law country dummy and the financial/tax accounting conformity dummy (adjusted R-Square: 14.7\%). This implies that the country dummies increase the explanatory power of the model and suggests that earnings management differences between countries are not merely driven by the common-law versus code-law distinction and financial/tax accounting conformity. For example, France and Germany are both code-law countries and both have conformity between financial accounting and tax rules. However, France and Germany differ significantly in the extent to which they engage in earnings management.

-INSERT TABLE 8-

Analogous to the test of means, the regression analysis is also done on the Big 5 audit firm sample and the non-Big 5 audit firm sample separately. The results are presented in table 9, panel A and B.

-INSERT TABLE 9 - 
Consistent with the results of the test of means, the multivariate analysis shows that the country differences remain significant, except for the Netherlands, even though all companies are audited by a Big 5 audit firm. The results further provide evidence that companies, audited by a Big 5 firm, that are listed on a foreign stock exchange engage significantly less in earnings management.

The OLS regression results for the non-Big 5 audit firm sample are presented in panel B of table 9. Consistent with the results of the test of means, the country difference in earnings management between Germany and the Netherlands is no longer significant for companies audited by a non-Big 5 firm. The performance measure, cash flow from operating activities is a significant control variable. Underperforming companies have a stronger incentive to manage their earnings.

\section{Summary and Conclusions}

The purpose of this study was to examine the effect of international differences in audit quality and audit environment on earnings management. The results of this study provide evidence that companies in Europe engage in earnings management. Consistent with the findings in the US (Hayn, 1995; Burgstahler and Dichev, 1997; Degeorge et al., 1999) and the UK (Gore et al., 2001), our results clearly indicate a discontinuity of scaled earnings around zero in the countries included in the study. This implies that companies in these countries prefer to avoid small losses and report small profits instead.

Our results further demonstrate that the magnitude of earnings management is not uniform across the four countries. In particular, the results suggest that companies in countries with flexible audit quality regimes (Germany and the Netherlands) report significantly higher absolute values of discretionary accruals compared to companies in countries with strict audit quality regimes (France and the UK). 
It is further shown that the country differences remain nearly all significant even in the presence of a Big 5 audit firm. This finding could imply that the conservatism of Big 5 audit firms in restricting earnings management does not appear to be uniform across countries.

Our results with respect to the incidence of earnings management by companies attracting international sources of capital are mixed. Companies audited by a Big 5 firm that are listed on a foreign stock exchange engage significantly less in earnings management. In contrast, companies, audited by a non-Big 5 firm, that are listed on a foreign stock exchange do not engage significantly less in earnings management. This result casts doubts upon the quality of certain non-Big 5 audit firms by allowing the earnings management practices of their clients to a great extent.

The results of this study are subject to the following limitations. First, as in almost every cross-country study, it can be questioned whether the observed differences between countries are really attributable to differences in earnings management. One could argue that they are driven by economic and institutional differences. We have partly controlled for economic differences by including industry differences. In addition, we believe that there are no major differences in the underlying economic situation between the four countries in the sample during the period under study. Therefore, the risk that economic differences have a significant impact on the results is considered to be low. It is acknowledged that there are institutional differences other than national audit environment between the countries under study. However, we have partly taken these institutional differences into account by controlling for common-law versus code-law accounting standards and conformity between financial and tax accounting rules. For example, although France and Germany both have code-law accounting standards and conformity between financial and tax accounting rules, they differ significantly in the extent to which they engage in earnings management. 
Second, consistent with previous research on earnings management, we have controlled for the following earnings management incentives: size, leverage and performance. Nonetheless, it is acknowledged that there may be other incentives to manage earnings across the countries in the sample that have not been explicitly controlled for.

Finally, the results suggest that there is an association between the magnitude of earnings management and the level of audit regulation. However, further research is needed to draw conclusions on the effectiveness of regulation in the audit market. 


\section{References}

Ali, A. and L. Hwang (2000), "Country-specific factors related to financial reporting and the value relevance of accounting data", Journal of Accounting Research, Vol.38, Spring, pp.1-21.

Ball, R., S.P. Kothari and A. Robin (2000), “The effect of international institutional factors on properties of accounting earnings", Journal of Accounting and Economics, Vol.29, February, pp.1-51.

Becker, C., M. DeFond, J. Jiambalvo and K. Subramanyam (1998), “The effect of audit quality on earnings management”, Contemporary Accounting Research, Vol.15, Spring, pp.1-24.

Blij, I., H. Hassink, G. Mertens and R. Quick (1998), "Disciplinary practices and auditors in Europe: a comparison between Germany and the Netherlands", The European Accounting Review, Vol.7, No.3, pp.467-491.

Brown, L. and H. Higgins (1999), "Managing earnings surprises in the US versus 13 other countries", Working paper, Georgia State University and Worcester Polytechnic Institute.

Buijink, W., S. Maijoor, R. Meuwissen, and A. van Witteloostuijn, The Role, Position, and Liability of the Statutory Auditor within the European Union, study commissioned by DG XV of the European Commission, Luxembourg: ECSC-EC-EAEC, 1996

Burgstahler, D. and I. Dichev (1997), "Earnings management to avoid earnings decreases and losses", Journal of Accounting and Economics, Vol.24, December, pp.99-126.

Dechow, P., R. Sloan and A. Sweeney (1995), "Detecting earnings management”, The Accounting Review, Vol.70, pp.193-225.

Dechow, P. and S.P. Kothari (1998), "The relationship between earnings and cash flows", Journal of Accounting and Economics, Vol.25, No.2, pp.133-169. 
DeFond, M. and J. Jiambalvo (1991), "Incidence and circumstances of accounting errors", The Accounting Review, Vol.66, pp.643-655.

DeFond, M. and J. Jiambalvo (1993), "Factors related to auditor-client disagreements over income-increasing accounting methods", Contemporary Accounting Research, Vol.9, Spring, pp.415-431.

DeFond, M. and J. Jiambalvo (1994), "Debt covenant violation and manipulation of accruals", Journal of Accounting and Economics, Volume 17, January, pp.145-176.

DeFond, M. and C. Park (1999), "The reversal of abnormal accruals and the market valuation of earnings surprises", Working paper, University of Southern California and Hong Kong University of Science and Technology.

Degeorge, F., J. Patel and R. Zeckhauser (1999), "Earnings management to exceed thresholds", Journal of Business, Vol.72, January, pp.1-33.

Francis, J., Maydew, E. and H. Sparks (1999), "The role of Big 6 auditors in the credible reporting of accruals", Auditing: A Journal of Practice and Theory, Vol.18, Fall, pp.17-34.

Gore, P., P. Pope and A. Singh (2001), "Discretionary accruals and the distribution of earnings relative to targets", Working paper, Lancaster University.

Hayn, C. (1995), "The information content of losses", Journal of Accounting and Economics, Vol.20, December, pp.125-153.

Healy, P. and J. Wahlen (1999), “A review of the earnings management literature and its implications for standard setting”, Accounting Horizons, Vol.13, pp.365-383.

Leuz, C., D. Nanda and P. Wysocki (2000), "Earnings management around the world", Working paper, Johann Wolfgang Goethe-Universitat and University of Michigan. 
Peasnell, K., P. Pope and S. Young (2000), “Detecting earnings management using cross-sectional abnormal accruals models", Accounting and Business Research, Vol.30, Autumn, pp.313-326.

Pope, P and M. Walker (1999), "International differences in the timeliness, conservatism, and classification of earnings", Journal of Accounting Research, Vol.37, Supplement, pp.53-87.

Young, S. (1999), "Systematic measurement error in the estimation of discretionary accruals: An evaluation of alternative modelling procedures", Journal of Business Finance and Accounting, Vol.26, September/October, pp.833-862.

Warfield, T., J. Wild and K. Wild (1995), "Managerial ownership, accounting choices and informativeness of earnings", Journal of Accounting and Economics, Vol.20, pp.61-91. 
Table 1: Overview of laws and regulations with respect to audit quality across countries

\begin{tabular}{|c|c|c|c|c|}
\hline & UK & NETH & GERMANY & FRANCE \\
\hline Length of the first audit mandate & 1 year $^{\mathrm{a}}$ & $\mathrm{n} / \mathrm{r}$ & $\mathrm{n} / \mathrm{r}$ & 6 years \\
\hline $\begin{array}{l}\text { Length of the renewed audit } \\
\text { mandate }\end{array}$ & 1 year $^{\mathrm{a}}$ & $\mathrm{n} / \mathrm{r}$ & $\mathrm{n} / \mathrm{r}$ & 6 years \\
\hline $\begin{array}{l}\text { Requirement on the number of } \\
\text { statutory auditors }\end{array}$ & no & no & no & $\begin{array}{l}\text { yes } \\
\text { a joint audit is } \\
\text { required for i.a. listed } \\
\text { firms }\end{array}$ \\
\hline $\begin{array}{l}\text { Requirement of approval of } \\
\text { appointment of statutory auditor }\end{array}$ & $\begin{array}{l}\text { no } \\
\text { except for banks and } \\
\text { other regulated } \\
\text { industries }\end{array}$ & no & $\begin{array}{l}\text { no } \\
\text { except for banks and } \\
\text { other regulated } \\
\text { industries }\end{array}$ & $\begin{array}{l}\text { yes } \\
\text { for listed firms, banks } \\
\text { and other regulated } \\
\text { industries }\end{array}$ \\
\hline Disclosure of audit fees & yes & no & no & no \\
\hline MAS allowed for statutory auditors & yes $^{b}$ & yes & yes $^{c}$ & no \\
\hline Advertising allowed & yes & yes & no ${ }^{\mathrm{d}}$ & no \\
\hline Peer review & no & no & no & $\begin{array}{l}\text { yes } \\
\text { every } 3 \text { years for } \\
\text { listed firms }\end{array}$ \\
\hline Review by regulators & $\begin{array}{l}\text { yes } \\
\text { every } 5 \text { years for } \\
\text { listed firms }\end{array}$ & no & no & $\begin{array}{l}\text { yes } \\
\text { every year }\end{array}$ \\
\hline Risk of litigation & high & moderate & low & low \\
\hline
\end{tabular}

\footnotetext{
${ }^{\text {a }}$ Private companies have the right to elect to do away with the requirement to re-elect statutory auditors each year. In that case, the statutory auditor remains appointed until positive action is taken to terminate the appointment.

${ }^{\mathrm{b}}$ The provision of bookkeeping and accounting services is forbidden in the case of listed or public-interest companies except if this is of a routine clerical nature. Audit firms within the same legal entity cannot provide legal services.

${ }^{c}$ The provision of bookkeeping and accounting services is forbidden.

${ }^{\mathrm{d}}$ Ethical advertising (general information on the auditor or audit firm) is allowed. However, unethical advertising (advertising that is directly aimed to gain new clients) is not allowed.
} 
Table 2: Descriptive statistics of scaled earnings across countries

\begin{tabular}{lcccccc} 
& $\mathrm{N}$ & Mean & Std. dev. & $\mathbf{2 5 \%}$ & $50 \%$ & $75 \%$ \\
\hline France & 3904 & 1.11 & 2.28 & 0.16 & 0.68 & 1.76 \\
Germany & 3992 & 0.88 & 2.12 & 0.06 & 0.58 & 1.55 \\
The Netherlands & 1244 & 0.91 & 1.19 & 0.34 & 0.72 & 1.22 \\
UK & 8698 & 0.89 & 2.24 & 0.04 & 0.64 & 1.31 \\
Pooled & 17930 & 0.96 & 2.21 & 0.09 & 0.65 & 1.44
\end{tabular}

Note: Earnings are measured as annual net income scaled by beginning of year total assets.

Figure 1: Distribution of scaled earnings for pooled sample

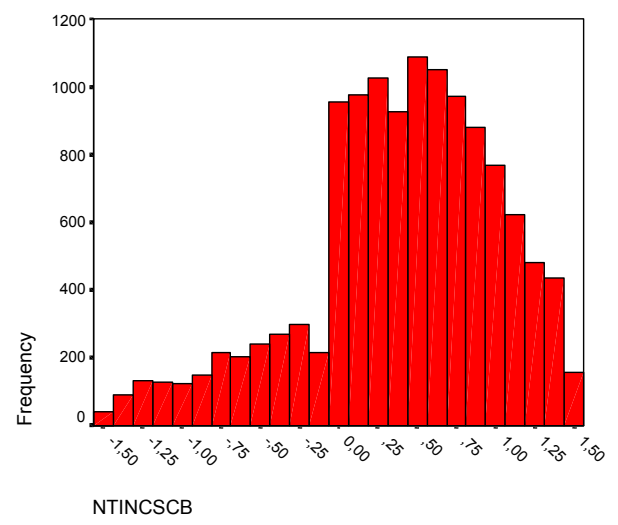

Table 3: Distribution of scaled near-zero earnings across countries

\begin{tabular}{lccccc} 
& $\begin{array}{c}\text { POOLED } \\
(\mathrm{n}=499)\end{array}$ & $\begin{array}{c}\text { FRANCE } \\
(\mathrm{n}=51)\end{array}$ & $\begin{array}{c}\text { GERMANY } \\
(\mathrm{n}=57)\end{array}$ & $\begin{array}{c}\text { NETH. } \\
(\mathrm{n}=12)\end{array}$ & $\begin{array}{c}\text { UK } \\
(\mathrm{n}=379)\end{array}$ \\
\hline $\begin{array}{l}\text { Std.difference } \\
\text { left of zero } \\
\text { (p-value) }\end{array}$ & -9.96 & -2.18 & -2.88 & -2.46 & -9.16 \\
\hline $\begin{array}{l}\text { Std.difference } \\
\text { right of zero }\end{array}$ & $(0.000)$ & $(0.014)$ & $(0.001)$ & $(0.006)$ & $(0.000)$ \\
$(\mathrm{p}-$ value) & 16.35 & 2.6 & 5.16 & 1.09 & 15.79 \\
\end{tabular}

Note: First interval right of zero: $[0.000,0.005)$, second interval: $[0.005,0.010)$, etc. 
Figure 2: Distribution abnormal working capital accruals in France

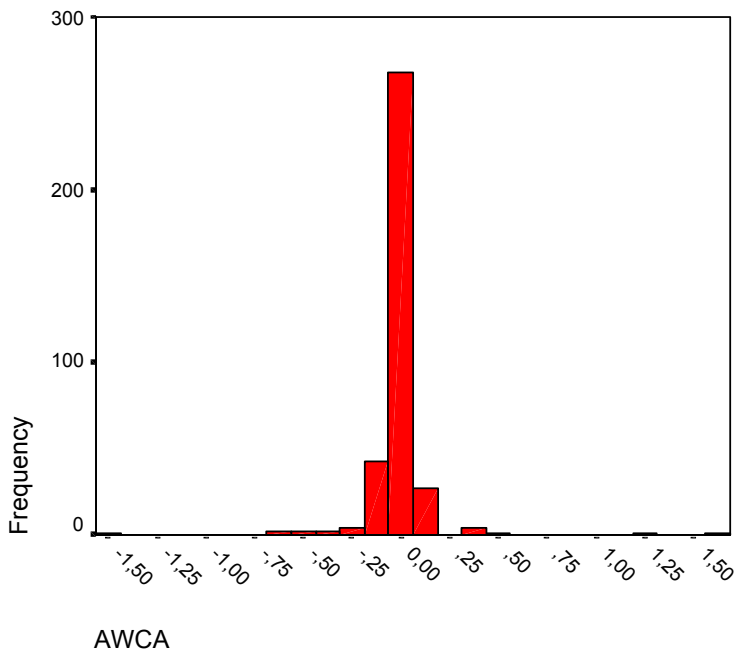

Figure 3: Distribution abnormal working capital accruals in Germany

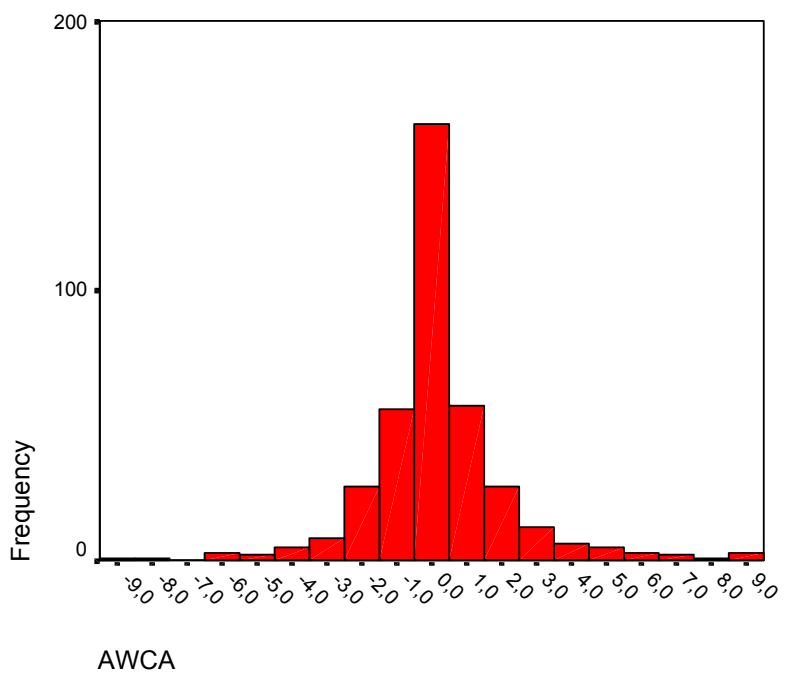


Figure 4: Distribution abnormal working capital accruals in the Netherlands

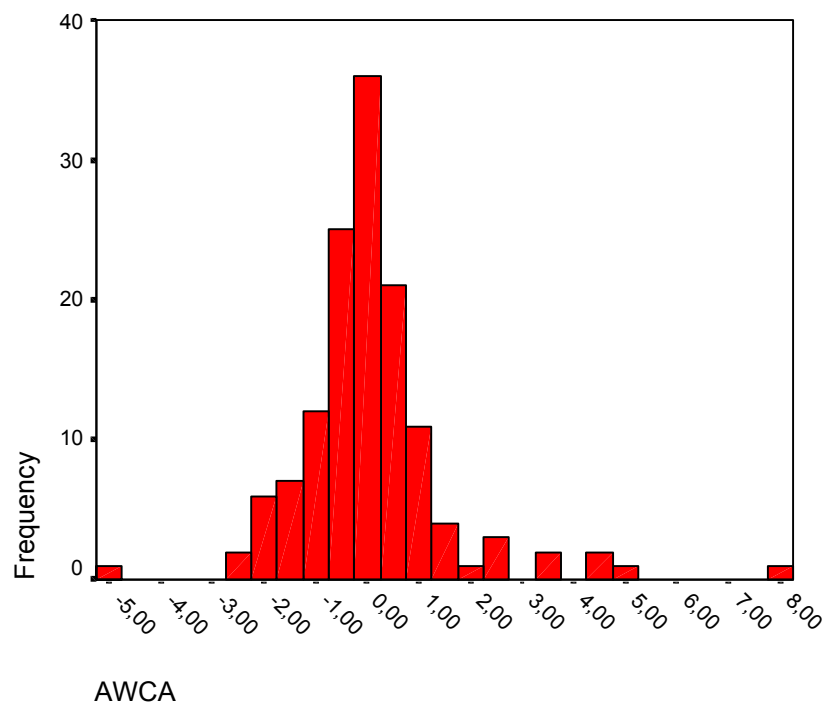

Figure 5: Distribution abnormal working capital accruals in the UK

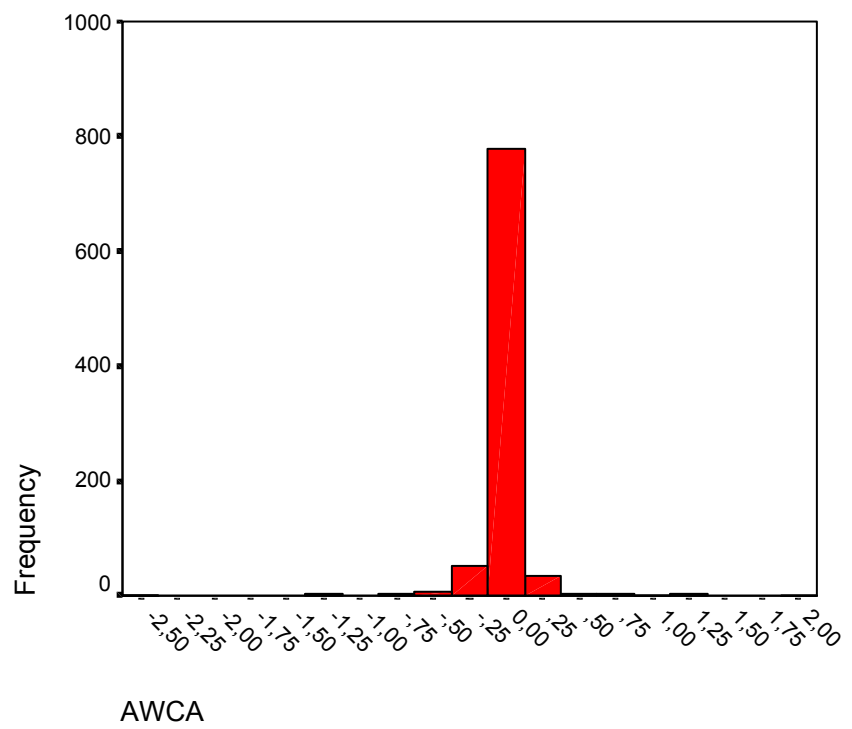

Table 4: Descriptive statistics of abnormal working capital accruals in absolute value across countries

\begin{tabular}{lcccccc} 
& $\mathrm{N}$ & Mean & Std. dev. & $25 \%$ & $50 \%$ & $75 \%$ \\
\hline France & 356 & 0.067 & 0.153 & 0.012 & 0.030 & 0.062 \\
Germany & 381 & 1.281 & 1.638 & 0.212 & 0.723 & 1.699 \\
The Netherlands & 135 & 0.896 & 1.160 & 0.235 & 0.472 & 1.143 \\
UK & 894 & 0.080 & 0.240 & 0.014 & 0.031 & 0.069 \\
Pooled & 1766 & 0.399 & 0.987 & 0.020 & 0.052 & 0.245
\end{tabular}


Table 5: Univariate results

\begin{tabular}{|c|c|c|c|c|c|}
\hline & POOLED & UK & NETH & GERM & FRANCE \\
\hline \multicolumn{6}{|l|}{ EARNINGS MANAGEMENT } \\
\hline AWCA $<0$ : income-decreasing & $-0.344(\mathrm{n}=928)$ & $-0.088(\mathrm{n}=472)$ & $-0.760(n=73)$ & $-1.15(n=181)$ & $-0.0667(n=202)$ \\
\hline $\mathrm{AWCA} \geq 0$ : income-increasing & $0.4601(n=838)$ & $0.072(\mathrm{n}=422)$ & $1.055(\mathrm{n}=62)$ & $1.39(\mathrm{n}=200)$ & $0.0689(n=154)$ \\
\hline Difference (significance) (2-tailed) & $\mathrm{t}=2.46(0.014)$ & $\mathrm{t}=0.9(0.32)$ & $\mathrm{t}=-1.47(0.143)$ & $\mathrm{t}=-1.4(0.153)$ & $\mathrm{t}=-0.138(0.89)$ \\
\hline \multicolumn{5}{|l|}{ BIG 5 vs. NON BIG 5} & \\
\hline Big 5 & $0.355(\mathrm{n}=1256)$ & $0.07(n=706)$ & $0.89(n=129)$ & $1.19(\mathrm{n}=221)$ & $0.072(n=200)$ \\
\hline Non-Big 5 & $0.546(\mathrm{n}=458)$ & $0.11(\mathrm{n}=156)$ & $0.82(\mathrm{n}=6)$ & $1.40(\mathrm{n}=155)$ & $0.061(\mathrm{n}=141)$ \\
\hline Difference (significance) (2-tailed) & $\mathrm{t}=-3.50(0.000)$ & $\mathrm{t}=-2.0(0.04)$ & $\mathrm{t}=0.14(0.884)$ & $\mathrm{t}=-1.21(0.226)$ & $\mathrm{t}=0.65(0.512)$ \\
\hline \multicolumn{6}{|l|}{$A W C A<0$ : income-decreasing } \\
\hline Big 5 & $-0.321(\mathrm{n}=691)$ & $-0.07(n=385)$ & $-0.75(n=70)$ & $-1.12(n=117)$ & $-0.076(n=119)$ \\
\hline Non-Big 5 & $-0.432(n=216)$ & $-0.15(n=75)$ & $-0.87(n=3)$ & $-1.22(\mathrm{n}=61)$ & $-0.051(\mathrm{n}=77)$ \\
\hline Difference (significance) (2-tailed) & $\mathrm{t}=1.735(0.083)$ & $\mathrm{t}=2.3(0.02)$ & $\mathrm{t}=0.24(0.806)$ & $\mathrm{t}=0.45(0.648)$ & $\mathrm{t}=-1.2(0.213)$ \\
\hline \multicolumn{6}{|l|}{$A W C A \geq 0:$ income-increasing } \\
\hline Big 5 & $0.3971(\mathrm{n}=565)$ & $0.069(\mathrm{n}=321)$ & $1.06(\mathrm{n}=59)$ & $1.28(\mathrm{n}=104)$ & $0.066(\mathrm{n}=81)$ \\
\hline Non-Big 5 & $0.6475(n=242)$ & $0.075(\mathrm{n}=81)$ & $0.78(n=3)$ & $1.52(\mathrm{n}=94)$ & $0.072(n=64)$ \\
\hline Difference (significance) (2-tailed) & $\mathrm{t}=-2.81(0.005)$ & $\mathrm{t}=-0.28(0.77)$ & $\mathrm{t}=0.32(0.746)$ & $\mathrm{t}=-0.93(0.353)$ & $\mathrm{t}=-0.20(0.837)$ \\
\hline \multicolumn{6}{|l|}{ FOREIGN LISTING } \\
\hline \multicolumn{6}{|l|}{ Absolute value $A W C A$} \\
\hline Foreign listing & $0.35(\mathrm{n}=83)$ & $0.058(n=35)$ & $0.56(n=17)$ & $0.87(n=18)$ & $0.13(n=13)$ \\
\hline No foreign listing & $0.40(n=1683)$ & $0.081(\mathrm{n}=859)$ & $0.94(n=118)$ & $1.3(\mathrm{n}=363)$ & $0.065(n=343)$ \\
\hline Difference (significance) (2-tailed) & $\mathrm{t}=-0.46(0.64)$ & $\mathrm{t}=-0.55(0.579)$ & $\mathrm{t}=-1.2(0.21)$ & $\mathrm{t}=-1.08(0.28)$ & $\mathrm{t}=1.5(0.12)$ \\
\hline \multicolumn{6}{|l|}{$A W C A<0:$ income-decreasing } \\
\hline Foreign listing & $-0.34(n=43)$ & $-0.077(n=22)$ & $-0.66(n=8)$ & $-0.77(n=10)$ & $-0.02(n=3)$ \\
\hline No foreign listing & $-0.34(n=885)$ & $-0.088(n=450)$ & $-0.77(n=65)$ & $-1.17(n=171)$ & $-0.06(n=199)$ \\
\hline Difference (significance) (2-tailed) & $\mathrm{t}=-0.01(0.987)$ & $\mathrm{t}=0.174(0.862)$ & $\mathrm{t}=0.34(0.73)$ & $\mathrm{t}=0.88(0.379)$ & $\mathrm{t}=0.57(0.56)$ \\
\hline \multicolumn{6}{|l|}{$A W C A \geq 0:$ income-increasing } \\
\hline Foreign listing & $0.35(\mathrm{n}=40)$ & $0.026(n=13)$ & $0.47(\mathrm{n}=9)$ & $0.99(n=8)$ & $0.16(n=10)$ \\
\hline No foreign listing & $0.46(n=798)$ & $0.073(n=409)$ & $1.15(n=53)$ & $1.41(n=192)$ & $0.06(n=144)$ \\
\hline Difference (significance) (2-tailed) & $\mathrm{t}=-0.59(0.55)$ & $\mathrm{t}=-1.01(0.311)$ & $\mathrm{t}=-1.2(0.20)$ & $\mathrm{t}=-0.63(0.52)$ & $\mathrm{t}=1.7(0.07)$ \\
\hline \multicolumn{6}{|l|}{ NYSE LISTING } \\
\hline \multicolumn{6}{|l|}{ Absolute value $A W C A$} \\
\hline NYSE listing & $0.25(\mathrm{n}=60)$ & $0.06(n=31)$ & $0.62(\mathrm{n}=7)$ & $0.77(n=11)$ & $0.039(\mathrm{n}=11)$ \\
\hline No NYSE listing & $0.39(\mathrm{n}=1489)$ & $0.08(n=775)$ & $0.91(n=110)$ & $1.24(\mathrm{n}=324)$ & $0.07(n=310)$ \\
\hline Difference (significance) (2-tailed) & $\mathrm{t}=-1.11(0.26)$ & $\mathrm{t}=-0.5(0.61)$ & $\mathrm{t}=-0.62(0.53)$ & $\mathrm{t}=-0.96(0.336)$ & $\mathrm{t}=-0.66(0.50)$ \\
\hline \multicolumn{6}{|l|}{$A W C A<0:$ income-decreasing } \\
\hline NYSE listing & $-0.29(n=36)$ & $-0.059(n=21)$ & $-0.76(n=4)$ & $-1.16(n=5)$ & $-0.05(n=6)$ \\
\hline No NYSE listing & $-0.33(n=775)$ & $-0.09(n=389)$ & $-0.80(n=57)$ & $-1.09(n=152)$ & $-0.707(n=177)$ \\
\hline Difference (significance) (2-tailed) & $\mathrm{t}=0.34(0.73)$ & $\mathrm{t}=0.47(0.634)$ & $\mathrm{t}=0.08(0.93)$ & $\mathrm{t}=-0.11(0.90)$ & $\mathrm{t}=0.24(0.807)$ \\
\hline \multicolumn{6}{|l|}{$A W C A \geq 0:$ income-increasing } \\
\hline NYSE listing & $0.19(n=24)$ & $0.06(n=10)$ & $0.43(n=3)$ & $0.45(n=6)$ & $1.98(\mathrm{n}=5)$ \\
\hline No NYSE listing & $0.45(\mathrm{n}=714)$ & $0.07(n=356)$ & $1.02(\mathrm{n}=53)$ & $0.38(\mathrm{n}=172)$ & $0.074(n=133)$ \\
\hline Difference (significance) (2-tailed) & $\mathrm{t}=-1.11(0.26)$ & $\mathrm{t}=-0.21(0.82)$ & $\mathrm{t}=-0.67(0.502)$ & $\mathrm{t}=-1.2(0.22)$ & $\mathrm{t}=-0.64(0.517)$ \\
\hline
\end{tabular}


Table 6: Test of means

Panel A: Pooled sample

Multiple Comparisons of absolute value of abnormal working capital accruals: Bonferroni test

$\begin{array}{llccc}\text { Country } \mathbf{i} & \text { Country j } & \text { Mean difference (i-j) } & \text { Standard error } & \text { Significance } \\ \text { Germany } & \text { France } & 1.213 & 0.062 & 0.000 \\ & \text { The Netherlands } & 0.385 & 0.084 & 0.000 \\ & \text { UK } & 1.200 & 0.051 & 0.000 \\ \text { France } & \text { The Netherlands } & -0.828 & 0.085 & 0.000 \\ & \text { UK } & -0.012 & 0.053 & 1.000 \\ \text { The Netherlands } & \text { UK } & 0.815 & 0.078 & 0.000\end{array}$

Panel B: Big 5 audit firm sample

Multiple Comparisons of absolute value of abnormal working capital accruals: Bonferroni test

$\begin{array}{llccc}\text { Country i } & \text { Country j } & \text { Mean difference (i-j) } & \text { Standard error } & \text { Significance } \\ \text { Germany } & \text { France } & 1.127 & 0.076 & 0.000 \\ & \text { The Netherlands } & 0.300 & 0.087 & 0.004 \\ & \text { UK } & 1.128 & 0.060 & 0.000 \\ \text { France } & \text { The Netherlands } & -0.827 & 0.089 & 0.000 \\ & \text { UK } & 0.0004 & 0.063 & 1.000 \\ \text { The Netherlands } & \text { UK } & & & 0.000\end{array}$

\section{Panel C: Non-Big 5 audit firm sample}

Multiple Comparisons of absolute value of abnormal working capital accruals: Bonferroni test

\begin{tabular}{|c|c|c|c|c|}
\hline Country i & Country $\mathbf{j}$ & Mean difference (i-j) & Standard error & Significance \\
\hline \multirow{3}{*}{ Germany } & France & 1.348 & 0.119 & 0.000 \\
\hline & The Netherlands & 0.580 & 0.426 & 1.000 \\
\hline & UK & 1.293 & 0.116 & 0.000 \\
\hline \multirow[t]{2}{*}{ France } & The Netherlands & -0.767 & 0.426 & 0.437 \\
\hline & UK & -0.055 & 0.119 & 1.000 \\
\hline The Netherlands & UK & 0.712 & 0.426 & 0.571 \\
\hline
\end{tabular}


Table 7: OLS regression results (Test model)

\section{Pooled sample}

$\begin{array}{lllll}\text { Variables } & \begin{array}{l}\text { Estimated } \\ \text { coefficient }\end{array} & \text { Standard error } & \text { t-statistic } & \text { Significance } \\ \text { Constant } & 0.944 & 0.389 & 2.429 & 0.015^{* *} \\ \text { UK } & -1.017 & 0.060 & -17.041 & 0.000^{* * *} \\ \text { FRA } & -1.025 & 0.077 & -13.394 & 0.000^{* * *} \\ \text { NETH } & -0.170 & 0.087 & -1.957 & 0.051^{*} \\ \text { B5NB5 } & -0.047 & 0.052 & -0.915 & 0.360 \\ \text { FORLIST } & -0.212 & 0.093 & -2.287 & 0.022^{* *} \\ \text { NYSE } & -0.016 & 0.111 & -0.151 & 0.880 \\ \text { LNASSET } & 0.009 & 0.018 & 0.569 & 0.569 \\ \text { GEAR } & -0.000 & 0.000 & -0.102 & 0.919 \\ \text { OPCF } & -0.000 & 0.000 & -2.255 & 0.024^{* *} \\ \text { SIC10-17 } & 0.105 & 0.102 & 1.023 & 0.306 \\ \text { SIC20-39 } & -0.022 & 0.070 & -0.321 & 0.748 \\ \text { SIC50-59 } & -0.030 & 0.080 & -0.388 & 0.698 \\ \text { SIC70-89 } & 0.147 & 0.083 & 1.769 & 0.077^{*} \\ \text { *p }<.10, * * p<.05, * * * p<.01 & & & \\ \text { R-Square: } 0.270 & & & \text { F-value: } 32.808 & \\ \text { Adjusted R-Square: } 0.261 & \text { Significance: } 0.000 & \end{array}$

Variables:

Dependent variable:

$\mathrm{AWCA}_{\mathrm{t}}=$ Abnormal working capital accruals in year $\mathrm{t}$

Independent variables:

$\mathrm{UK}=$ Dummy variable (UK company $=1$, else 0$)$;

FRA = Dummy variable (French company $=1$, else 0$)$;

$\mathrm{NETH}=$ Dummy variable $($ Dutch company $=1$, else 0$)$;

$\mathrm{B} \mathrm{NB}_{\mathrm{t}}=$ Dummy variable $($ Company has Big 5 auditor $=1$, else 0$)$;

FORLIST $_{t}=$ Dummy variable (Company has a foreign listing $=1$, else 0 );

$\mathrm{NYSE}_{\mathrm{t}}=$ Dummy variable (Company is listed on the NYSE = 1, else 0 );

LNASSET $_{\mathrm{t}}=$ Natural logarithm of total assets in year $\mathrm{t}$;

$\mathrm{GEAR}_{\mathrm{t}}=$ Ratio of long term debt over common equity in year $\mathrm{t}$;

$\mathrm{OPCF}_{\mathrm{t}}=$ Cash flow from operating activities in year $\mathrm{t}$.

SIC 10-17: Mining \& Construction

SIC 20-39: Manufacturing

SIC 50-59: Wholesale trade

SIC 70-89: Services 
Table 8: OLS regression results (Alternative model)

\section{Pooled sample}

$\begin{array}{lllll}\text { Variables } & \begin{array}{l}\text { Estimated } \\ \text { coefficient }\end{array} & \text { Standard error } & \text { t-statistic } & \text { Significance } \\ \text { Constant } & 0.690 & 0.423 & 1.632 & 0.103 \\ \text { COMLAW } & -0.849 & 0.079 & -10.747 & 0.000^{* * *} \\ \text { TAXCONF } & -0.304 & 0.085 & -3.571 & 0.000^{* * *} \\ \text { B5NB5 } & -0.106 & 0.055 & -1.910 & 0.056^{*} \\ \text { FORLIST } & -0.170 & 0.100 & -1.705 & 0.088^{*} \\ \text { NYSE } & -0.025 & 0.119 & -0.210 & 0.834 \\ \text { LNASSET } & 0.015 & 0.019 & 0.823 & 0.410 \\ \text { GEAR } & -0.000 & 0.000 & -0.206 & 0.837 \\ \text { OPCF } & -0.000 & 0.000 & -2.657 & 0.008^{* * *} \\ \text { SIC10-17 } & 0.099 & 0.110 & 0.905 & 0.365 \\ \text { SIC20-39 } & 0.034 & 0.075 & 0.466 & 0.641 \\ \text { SIC50-59 } & -0.007 & 0.086 & -0.093 & 0.926 \\ \text { SIC70-89 } & 0.108 & 0.089 & 1.213 & 0.225 \\ \text { *p }<.10, * * p<.05, * * * p<.01 & & & \\ \text { R-Square: } 0.156 & & & \text { F-value: } 17.838 & \\ \text { Adjusted R-Square: } 0.147 & & \text { Significance: } 0.000 & \end{array}$

where:

COMLAW $=$ Dummy variable $($ COMLAW $=1$, in case of common-law country, else COMLAW $=0$, in case of code-law country);

TAXCONF $=$ Dummy variable $(\mathrm{TAXCONF}=1$, in case of country with conformity between tax and accounting rules, else TAXCONF $=0$ ). 
Table 9: OLS regression results

Panel A: Big 5 audit firm sample

$\begin{array}{lllll}\text { Variables } & \begin{array}{l}\text { Estimated } \\ \text { coefficient }\end{array} & \text { Standard error } & \text { t-statistic } & \text { Significance } \\ \text { Constant } & 1.008 & 0.409 & 2.466 & 0.014^{* *} \\ \text { UK } & -0.956 & 0.069 & -13.823 & 0.000^{* * *} \\ \text { FRA } & -0.957 & 0.088 & -10.835 & 0.000^{* * *} \\ \text { NETH } & -0.111 & 0.091 & -1.213 & 0.226 \\ \text { FORLIST } & -0.201 & 0.091 & -2.212 & 0.027^{* *} \\ \text { NYSE } & -0.033 & 0.109 & -0.031 & 0.975 \\ \text { LNASSET } & 0.001 & 0.018 & 0.091 & 0.927 \\ \text { GEAR } & 0.000 & 0.000 & 0.676 & 0.499 \\ \text { OPCF } & -0.000 & 0.000 & -1.387 & 0.166 \\ \text { SIC10-17 } & 0.129 & 0.110 & 1.171 & 0.242 \\ \text { SIC20-39 } & -0.020 & 0.076 & -0.268 & 0.789 \\ \text { SIC50-59 } & -0.040 & 0.085 & -0.471 & 0.638 \\ \text { SIC70-89 } & 0.115 & 0.090 & 1.281 & 0.200 \\ \text { *p }<.10, * * p<.05, * * * p<.01 ~ & & & \\ \text { R-Square: } 0.255 & & & \text { F-value: } 25.841 & \\ \text { Adjusted R-Square: } 0.245 & & \text { Significance: } 0.000 & \end{array}$

Panel B: Non-Big 5 audit firm sample

$\begin{array}{lllll}\text { Variables } & \begin{array}{l}\text { Estimated } \\ \text { coefficient }\end{array} & \text { Standard error } & \text { t-statistic } & \text { Significance } \\ \text { Constant } & 0.087 & 1.081 & 0.081 & 0.936 \\ \text { UK } & -1.199 & 0.127 & -9.418 & 0.000^{* * *} \\ \text { FRA } & -1.192 & 0.164 & -7.286 & 0.000^{* * *} \\ \text { NETH } & -0.429 & 0.385 & -1.113 & 0.267 \\ \text { FORLIST } & -0.458 & 0.517 & -0.885 & 0.377 \\ \text { NYSE } & -0.364 & 0.640 & -0.569 & 0.570 \\ \text { LNASSET } & 0.058 & 0.049 & 1.182 & 0.238 \\ \text { GEAR } & -0.000 & 0.000 & -1.588 & 0.114 \\ \text { OPCF } & -0.000 & 0.000 & -1.995 & 0.047^{* *} \\ \text { SIC10-17 } & 0.070 & 0.272 & 0.260 & 0.795 \\ \text { SIC20-39 } & -0.035 & 0.175 & -0.201 & 0.841 \\ \text { SIC50-59 } & -0.033 & 0.211 & -0.159 & 0.874 \\ \text { SIC70-89 } & 0.254 & 0.204 & 1.246 & 0.214 \\ \text { *p }<.10, * * p<.05, * * * p<.01 ~ & & & \\ \text { R-Square: } 0.315 & & & \text { F-value: } 9.114 & \\ \text { Adjusted R-Square: } 0.280 & & \text { Significance: } 0.000 & \end{array}$

